\title{
The traditional and therapeutic use of banana and its plant based delicacies in ethnic Assamese cuisine and religious rituals from Northeast India
}

\author{
Upasana Sarma ${ }^{1 *}$, Viney Kumar Govila² and Akanksha Yadav ${ }^{3}$
}

\begin{abstract}
Assam lies nestled in the far north-east corner of the Indian subcontinent. A country blessed with ample natural resources, the state of Assam also has a plethora of options in terms of choosing their core food sources. Banana or kol, as named in Assamese, has hundreds of varieties available in many parts of the world. They grow particularly well in tropical countries. It is found abundantly in the state of Assam and people have been making judicious use of the fruit and its plant parts in their cuisine since time immemorial. But nevertheless, a detailed review on its uses and importance and rising popularity in ethnic delicacies has not yet been documented well. This paper attempts to bring together the popular banana-based recipes of Assam state and its use in everyday religious ceremonies by the people of this community. It has age-old recipes used commonly in Assamese households and descriptive analysis of their microbial and biochemical diversity. It aims to bring to the fore the rising popularity of these ethnic dishes amongst modern population and is an attempt to revive these dishes and bring them into the mainstream Indian ethnic cuisine. As more and more people become aware of ethnic cuisine, it increases a global connectivity based on exchange of such information from lesser-known sources. The importance and significance of documenting these lesser-known recipes of Indian Assamese cuisine is an attempt to keep it relevant and take it to a broader audience who are appreciative of such oriental dishes. It is also high time a policy framework is worked upon by respective government of state and the centre for the true recognition and sustainability of such ethnic cuisine.
\end{abstract}

Keywords: Banana, Assamese, Ethnic cuisine, Kol, Traditional, Kaskol, Therapeutic, Food diversity

\section{Introduction}

Banana as a fruit has multitude of health benefits. It has been a common practise of nutritionists and physicians to recommend banana in one's regular dietary plans [1]. But what is lesser known is its plant-based utility in ethnic dishes of many Indian states. The herbaceous plants under genus Musa are commonly called as banana. The trunk is actually a pseudo stem are called 'false stem'. It is one of the oldest cultivated plants of the world and

\footnotetext{
* Correspondence: upasanasarma20@gmail.com

${ }^{1}$ Department of Microbiology, Faculty of Allied Health Sciences, Sri Guru

Govind Singh Tricentenary University, Gurugram, India

Full list of author information is available at the end of the article
}

harbours many therapeutic uses. All parts of the banana plant are extensively used in the Assamese community of Northeast India. Locally it is known as 'bhimkol' or 'athiyakol'. They use it in preparation of ethnic dishes like Khar to meat and fish-based dishes which are indigenous to the community. As a tropical fruit, banana plant grows abundantly across the state of Assam. Its easy availability and high nutritious content have made it a common household ingredient amongst the people of Assamese community. The basic preparation of each dish involving the use of banana or any of its edible plant part varies from tribe to tribe within the state of Assam. Since very less recorded data is available on such

(c) The Author(s). 2020 Open Access This article is licensed under a Creative Commons Attribution 4.0 International License, which permits use, sharing, adaptation, distribution and reproduction in any medium or format, as long as you give

appropriate credit to the original author(s) and the source, provide a link to the Creative Commons licence, and indicate if changes were made. The images or other third party material in this article are included in the article's Creative Commons licence, unless indicated otherwise in a credit line to the material. If material is not included in the article's Creative Commons licence and your intended use is not permitted by statutory regulation or exceeds the permitted use, you will need to obtain permission directly from the copyright holder. To view a copy of this licence, visit http://creativecommons.org/licenses/by/4.0/. 
dishes, every household prepares it in their own unique way yet there is very little variation in the core ingredients [2].

A diverse population of people comprising of many tribes constitute the state's population. Some of the common tribes inhabiting the state of Assam are Bodos, Mising, Karbis, Rabha and Mikir to name a few [3]. The Mising tribe which is one of the largest tribe inhabiting the state boasts of many ethnic preparations that involve the use of banana flower also called as 'koldil' or 'kolphul'. The banana leaves are also commonly used to wrap meat preparations and steam it under the fire (also called 'patot dia'). A large number of fermented delicacies depend on the use of banana leaves for their preparations [4].

The microbial diversity and biochemical content of these ethnic dishes based on bananas have not been studied to a large extent. Antibacterial activity of banana peel has been documented in certain studies along with their phytochemical analysis but scientific validation is still an issue in such cases. Depiction of 'wild banana' in scientific literature has slowly gained more momentum in recent times [5]. Banana peel and parts of the fruit are a great source of antioxidants and contain high amount of polyphenols, flavonoids, phenolics, catecholines and many other important phytochemicals. Many types of phytosterols have also been reported in banana which includes stigmasterol and sitosterol to name a few. Most parts of the plant have also been reported to have medicinal values to a great extent. There are also review reports available to validate the traditional knowledge available on banana [6].

The tradition of preparing ethnic foods not only garners creativity but it is also a bridge that connects the socio-cultural, spiritual, economic and way of life of the concerned communities. The current global food market scenario has started looking into such ethnic dishes from a broader perspective as they are deeply connected to the socio-economic and cultural diasporas of various lesser-known communities within a state. Tribal people often live in harmony with nature and make the best use of resources available to mankind [7]. A good deal of awareness on local cuisine also indirectly leads to a boom in the tourism sector. The state of Assam which is famous for its biodiversity national park Kaziranga can also boast of a cuisine that is deeply rooted in rich tradition and nature.

In today's times, the role of culinary tourism is immense. Tourism and unique food experiences go hand in hand. Promotion of ethnic food is a key component in increasing influx of tourists. A major reason why people travel to even the remote corners of any country is to experience its natural beauty and their ethnic cuisine. Assam is a state amply blessed in both sectors.
Popularly known as 'paradise unexplored' the entire northeastern belt of India which also comprises of Assam has a rich food experience to offer in terms of authenticity as well as ethnicity. Its deep-rooted traditions have given rise to unique dishes that have undergone changes from generation to generation and yet thrived to make its mark in the global food scenario. Through scientific documentation of lesser-known recipes one can highlight the socio-economic significance of the region in a scientific manner [8] (Fig. 1).

\section{Banana the superfood?}

Any food that gives maximum nutrition with minimum calorie intake can be termed as 'super food'. However no definite description has been universally accepted for this term. Most super foods come from plant-based sources. Also, studies on the nutritional content of the banana stem have been rarely documented in scientific literature. Banana has been an integral part of Assamese nutritional diet charts for as long as one can remember. Many a group of scientists have tested the nutritional requirement of malnourished school children by supplementing a banana-based breakfast. This in itself is a sign of the common use of banana even in the grassroots level of nutritional assessment in various districts of Assam. Even on a global level, research has been on a rise to assess all aspects of phytonutrients present in banana and the changes it undergoes in the ripening process [9] (Fig. 2).

A study conducted by the Assam Agricultural University states the use of banana leaves to wrap fish or meat items and steam them over a traditional fire. The study was an initial attempt to document nutritional status of ethnic Assamese delicacies [10]. In therapeutic terms as well, the use of banana in dietary charts are commonly found amongst people of Assam. Banana was the fruit of choice amongst patients of head and neck cancer kept under palliative care. Banana was chosen as it is easily available, cheap and has good nutritive value. Many a times, banana has been used to treat various kinds of deficiencies and even alleviate Vitamin A deficiencies especially in developing countries [11]. Though the extensive use of banana and its leaves in south Indian cuisine has been studied and documented to a great extent, its rampant use in Assamese ethnic food scene is yet to get its fair share of attention amongst scientists and researchers. There have also been studies conducted on the nutritional application of ethnic food in Southeast Asian population living in the UK [12]. The fact is that culinary banana peel has not been studied in depth and a group of scientists from Assam has attempted recently to document and identify the different active compounds at a particular stage of maturity of a banana plant. It stated that culinary banana peel can also serve as a potential biomaterial in industrial applications 


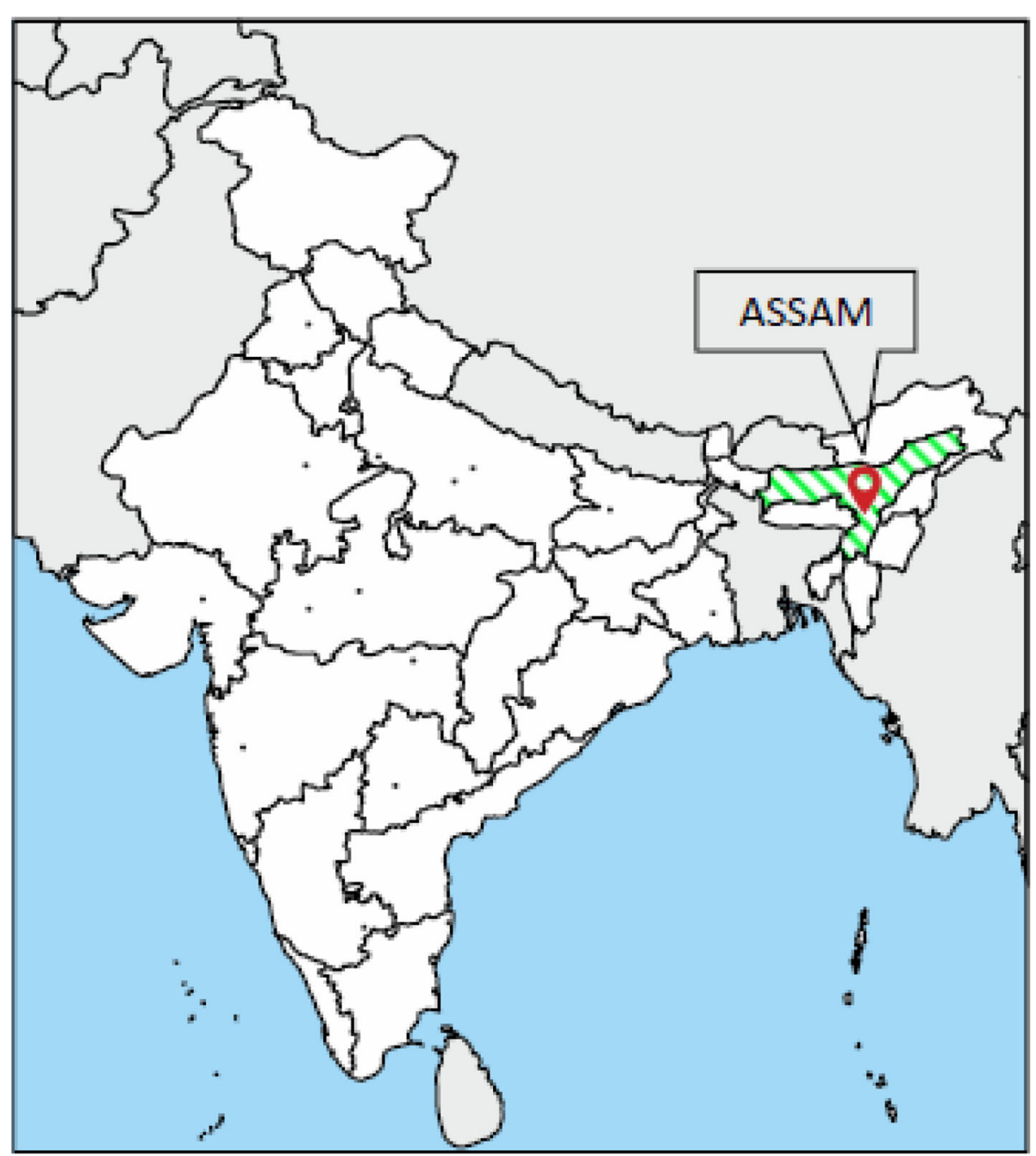

Fig. 1 Map of India and state of Assam as marked in green (map has been adapted from https:/d-maps.com/carte.php?num_car=70688\&lang=en)

and can add a higher value to this locally important and underutilized crop in all aspects. Reviews on the health benefits of banana bioactive compounds have been able to concisely evaluate and summarise the good effects of banana peel and its utilisation in food industry [13].

\section{Tribes of Assam and their unique utilisation of banana in recipes}

Assam is home to many tribal communities each with their unique food sensibilities. Usually, every Assamese household has a home garden which harbours common plants found in the region. Indigenous plant species have provided the local population with good level of nutrients in Assam as well as in the entire northeast of India [14]. The banana plant is one of the most common plants which grows abundantly across the entire length and breadth of the state. The Meitei community of Rajubari, Assam, is one such tribal community whose home gardens commonly grows banana plant. The use of banana blossom is common amongst all communities of Assam. It is commonly used for preparation of meat like duck meat or pigeon meat. The effect of banana blossom was studied in high-cholesterol fed rats and based on the data found, it was speculated that banana blossom incorporated experimental diets may modulate the hypo cholesterolaemic and hypoglycaemic responses in Wistar rats [15] (Fig. 3).

A study conducted on food habits of pre-colonial Assam also states the multi-diverse use of banana and its leaves in ethnic cuisine. The usual curry was prepared with fish and alkali extract of banana roots. The traditional 'jalpan' of Assam also has banana as one of its core ingredients. The koldil or banana cone was used to prepare various dishes. The thinly pieced banana cone with pigeon meat was a unique specialty even in those times. It has been classified into the dessert or sweet bananas and the cooking bananas or plantains. It is either eaten raw or processed, and also as a functional 


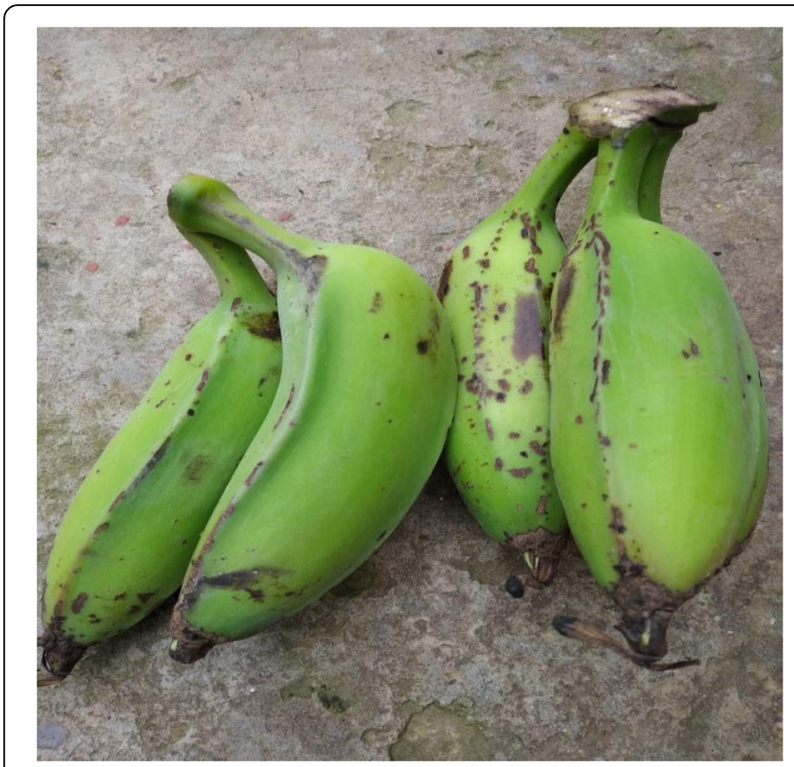

Fig. 2 Image showing 'Kaskol' from a market in Assam

ingredient in various food products [16]. The Bodo community which comprises of a large chunk of Assamese indigenous population also makes use of banana and its parts in their delicacies as well as for therapeutic reasons. The dietary habits of Bodos mostly depend on the local sources of variety of vegetables and non-vegetarian food items. The Bodo inhabitants of Baksa district of Assam are also well adapted with their natural surroundings and forest resources for their livelihood and they practise indigenous knowledge of ethnic food preparation. A study on the gut bacterial profile of these tribes

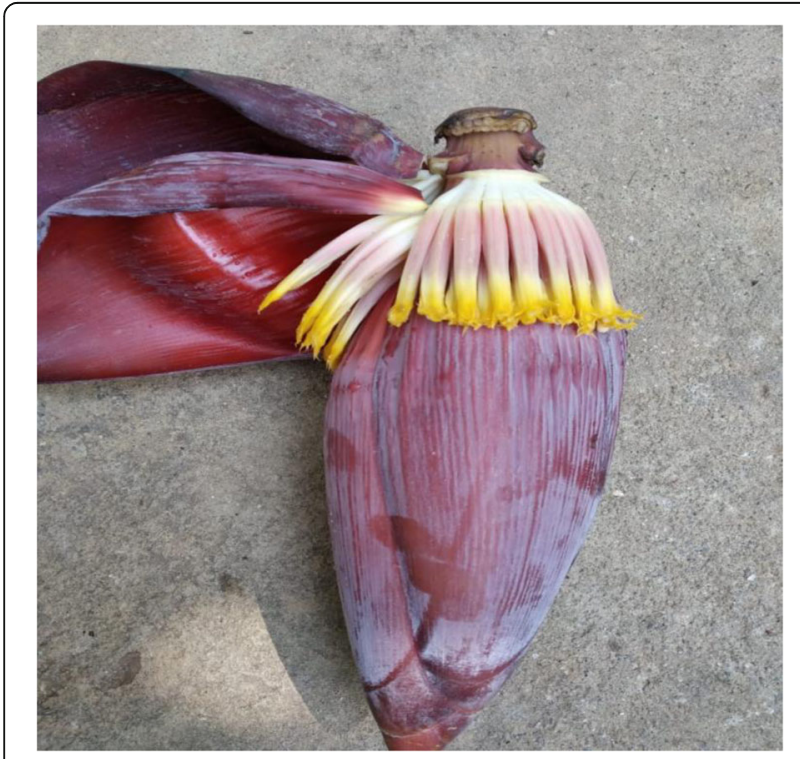

Fig. 3 Image depicting a 'koldil' from a market in Assam of India (including Assam) has also revealed significant data on their similarities with other such tribes around the world [17]. The Dimasa tribe of the state also makes use of the banana leaf as a covering for many of the local dishes they make out of bamboo shoots. One such dish is Mia mikhri which can be either consumed as a pickle or as a curry. Amongst the common wild herbs and vegetables used by the tribe are wild banana, wild brinjal and tomato. The use of zootherapeutic amongst Biate tribe of Dima Hasao District of Assam has also been addressed in a study [18]. Such studies have helped to create awareness on the optimum utilisation of resources of tribes of Assam. 'Guduyaba' (small fish or vegetables wrapped and smoked within banana leaves and kept under the hot ashes of mud-ovens) is a local cuisine of Dimasas living in the Karbi Anglong district of Assam. Some Karbi traditional dishes like 'Kimung' and 'kangthu' make use of banana leaves commonly. The use of banana especially its leaves and stem are extremely common in all major districts of the state of Assam. They also use most plant species for medicinal purposes which in turn have turned traditional healing into a much sought after field [19].

\section{Banana and its plant-based delicacies Kolakhar}

The commercial importance of 'kolakhar' is immense amongst various tribes of Assam. Musa balbisiana, the seedy variety of banana plant found commonly in the state is considered to be the best as far quality of kolakhar is concerned. It a product commonly produced in the winter months and used for the rest of the year. Traditionally, banana trunk, rhizome and peels are most commonly used for the preparation of kolakhar. The plant parts are cut into pieces and they are sun dried for several weeks. This is then burnt into ashes and extracted with water. The ashes are then made to pass through a bamboo made sieve and water which is added over it is allowed to trickle down the ashes. The filtrate thus obtained is called as kolakhar.

\section{Kol posola}

Young banana pseudo-stem is cooked as vegetable (called posola) which is a very rich source of iron and fibres [20]. It is prepared like any other Indian curry recipe. Common combinations of food item are posola with dal and posola with fish which is prepared in gravy of onion and all common Indian spices including ginger garlic paste, cardamom and chillies. Though hardly any scientific study has been reported in depth on its nutritional aspects, a few blogs have been found to summarise and mention the uses and presence of its high content of calcium, iron and manganese. 


\section{Koldil bhaji (fried banana flower)}

The banana flower is also known as banana blossom or banana heart. It is rich in vitamins, essential and nonessential amino acids and tannins. It is extensively used in many Indian cuisines including south Indian and Bengali recipes. The Assamese tribal community makes use of banana flower is a simple and rustic way of cooking with minimum spices. The banana flowers are peeled and cut into small pieces. In a little amount of oil, it is fried with cubes of potatoes. Sometimes the koldil is mixed with pre-cooked dal and other spices and fried till it is cooked to perfection (Fig. 4).

\section{Koldil mangxho}

The koldil or banana blossom is commonly used to make various types of non-vegetarian preparations in traditional Assamese households. Commonly used are country chicken and pigeon meat. It is usually cooked in light-simmering gravy of onion paste, ginger garlic paste and whole spices. The tender meat and banana flower is kept under medium flame until it turns into tender meat and hearty gravy.

\section{Kaskol bhaji/bor}

Kaskol bhaji is a simple stir-fried recipe of raw banana. It uses minimum spices and is simply pan fried with a few spices. It is considered to be a prominent vegetable used in Assamese cuisine (Fig. 5).

\section{Kaskol dia maas}

One of the most savoured and authentic dishes used by Assamese people are kaskol dia mass (raw banana-based fish curry). Like most other Assamese delicacies, this

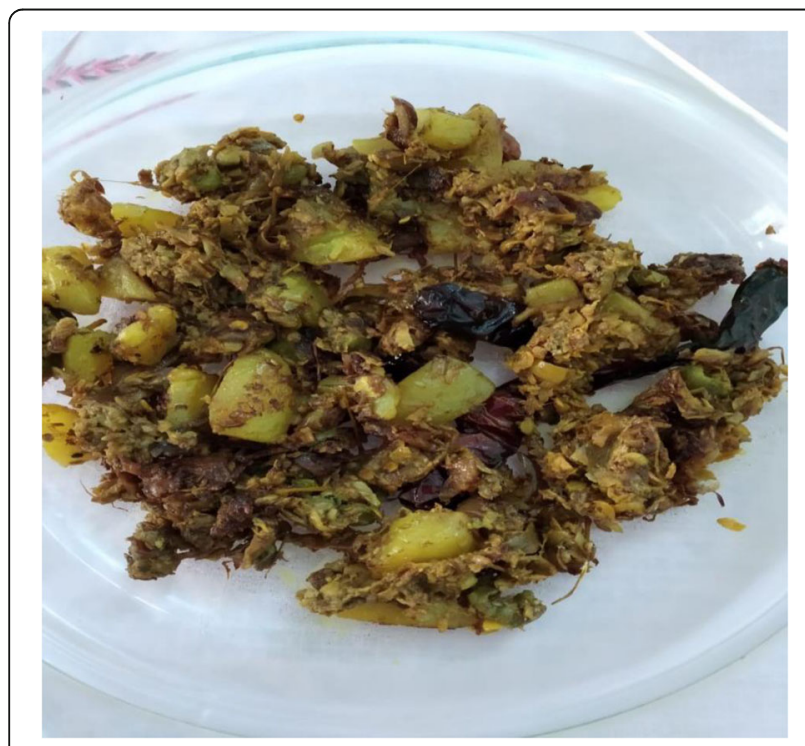

Fig. 4 Image shows a preparation of 'koldil bhaji'

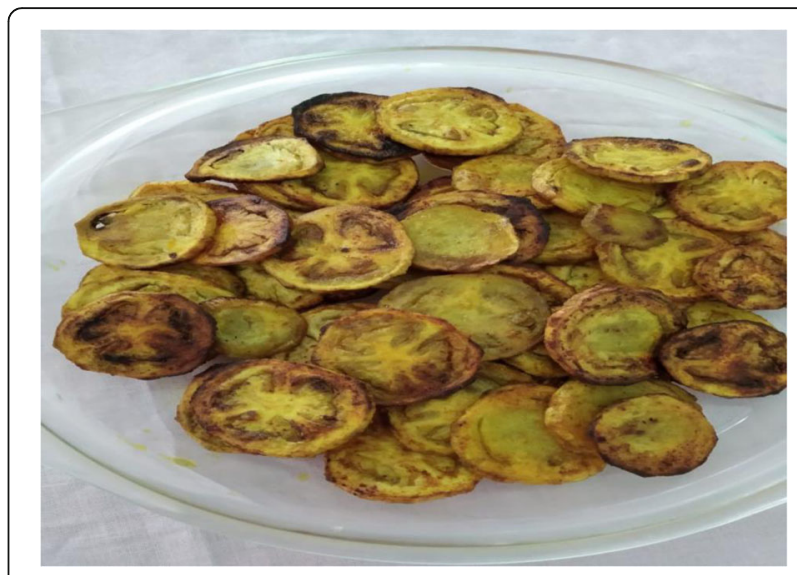

Fig. 5 Image shows a dish of 'kaskol bhaji'

curry is also made in a simple manner with limited spices. The most common form of curry is made by using a herb called 'skunk vine' which has a very strong odour and slightly bitter taste. It is usually served hot with rice.

\section{Kaskol pitika}

Mashed raw banana or kaskol pitika as locally called is a common side dish in authentic Assamese lunch scenes. The mashed mix usually has chillies, mustard oil, few garlic pods and chopped onions along with the main ingredient of raw bananas.

\section{Patot dia maas}

This is one of the most popular fish-based dishes of Assam wherein the use of banana leaves is seen for steaming over a fire (fish steamed in banana leaves). It is a blend of native flavours amalgamated with significant regional influences.

\section{Kol pitha}

It is a traditional homemade Assamese sweet delicacy made of banana. It is either steamed or deep fried as fritters. Pithas are the quintessential sweet savouries from Assamese cuisine relished across the state and amongst the Assamese community during the Bihu Festival. The traditional Kol Pitha is a steamed one, encapsulated and wrapped in banana leaves. The batter is wrapped in banana leaves and left to steam until done.

\section{Jolpan}

It is a traditional Assamese breakfast item savoured by the people of the state especially during festivals like Bihu. It is sometimes customised with the uses of sliced bananas along with other savouries. The traditional jalpan is served to guests in wedding and other family or community functions. Sandah guri or roasted rice powder is taken with milk, curd and banana. 


\section{Use of banana and its parts in religious ceremonies across Assam}

The use of banana and its parts have been common in Assamese religious rituals since time immemorial. Extensive use of banana is especially common amongst Assamese Hindu who mostly inhabits plain regions of the state. From weddings to funerals, the banana finds its way in almost all religious functions across the state. From the banana sapling to its trunk, most parts of banana find optimum utilisation in these rituals.

\section{Duna (kolpotia)}

It is a special vessel made from the peel of banana trees. It is commonly used in traditional marriage ceremonies as well as in religious rituals across the state of Assam.

\section{Leaves}

As mentioned earlier, banana leaves are utilised both in ethnic steaming techniques of Assamese cuisine as well as in religious ceremonies called 'puja'. From covering to preparing delicious ethnic items the use of banana leaves is immense. The common modes of cooking in Assamese cuisine are boiling, steaming, frying, baking, grilling and baking in foil of banana leaf (Fig. 6).

\section{Fruit (Bhug)}

The ripe bananas are extensively used in traditional religious ceremonies to prepare 'bhog'. The peeled bananas are mashed to a pulp along with sugar as per taste. Melted jaggery is added in about half a litre of milk. Then heated ghee is added and a fine sieve is used to remove any impurities or particles from the flour which is added at last. All of the ingredients are added and mixed properly until all lumps are removed.

\section{Discussion}

Bananas are amongst the world's leading food crops, after rice, wheat and maize. Almost ninety percent of production is consumed in the production areas, especially in countries

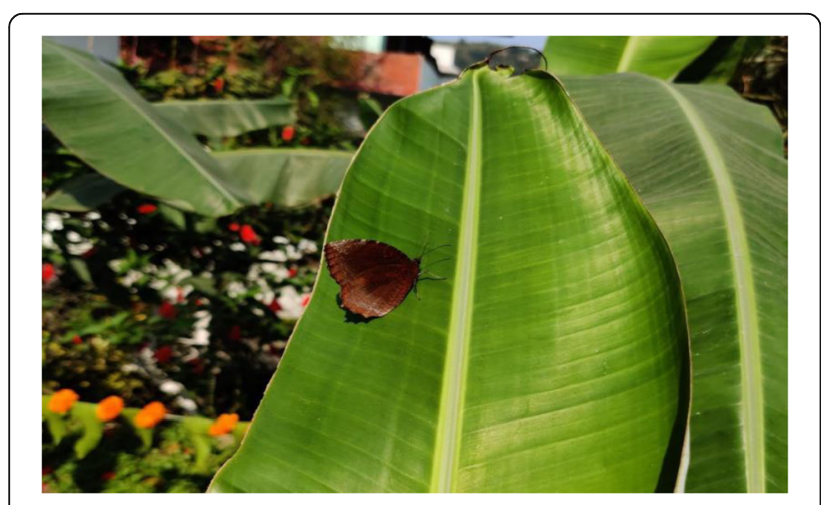

Fig 6 Image shows a mature banana leaf in a garden in Assam in Africa, Latin America and Asia. In certain regions, pureed banana is the first solid food given to infants. It undergoes significant textural and colour transformations during the ripening process, which in turn influence the eating quality of the fruit [21]. In Assam, though banana has been extensively used, its peel is still under utilised. Like its pulp flour counterpart, banana peel flour can potentially be used in new products with standardised composition for various industrial and domestic uses. Banana peel and pulp have also been documented as a potent source of raw material for the development of phytomedicine and even allopathic medicines [22]. The enormous by products of banana food industry are an excellent source of raw materials for other industries by recycling agricultural waste. This prevents loss of untapped biomass and helps negate environmental issues [23].

Banana-based recipes have been an integral part of Assamese cuisine and its food cultural diversity. A state which is home to many tribes, the use of banana and its leaves in the cuisine of all these indigenous ethnic groups is a beautiful sign of common food tradition. There is a plethora of opportunities to be explored using banana as a base to even work on newer recipes representing the local food culture of this Indian northeastern state of Assam. These banana-based dishes can serve as a mark of culture and ethnicity of the Assamese people. Moreover, bananabased recipes has been a trademark of ethnic Assamese cuisine since ages and it is high time to popularise it and spread it worldwide for the benefit of tourism and upliftment of the community in general. This work has tried to summarise the multiple uses of banana and its parts in local Assamese food and has been an honest effort to document it in a scientific manner.

\section{Acknowledgements}

We would like to express our heartfelt gratitude to SGT University for providing us with a platform to discuss innovative ideas of research and also help us in implementing them.

\section{Authors' contributions}

The first author planned and conceived the main body of work. The second author was instrumental in giving important inputs to this manuscript. The third author helped in editing this manuscript. The authors read and approved the final manuscript.

\section{Funding}

This is a self-funded work by the authors.

Availability of data and materials

The data mentioned was thoroughly analysed and reported in this work

\section{Competing interests}

The authors declare that they have no competing interests.

\section{Author details}

'Department of Microbiology, Faculty of Allied Health Sciences, Sri Guru Govind Singh Tricentenary University, Gurugram, India. ${ }^{2}$ Dean, Faculty of Allied Health Sciences, Sri Guru Govind Singh Tricentenary University, Gurugram, India. ${ }^{3}$ Department of Nutrition and Dietetics, Faculty of Allied 
Health Sciences, Sri Guru Govind Singh Tricentenary University, Gurugram, India.

Received: 11 February 2020 Accepted: 8 May 2020

Published online: 05 June 2020

\section{References}

1. Slavin JL, Llyod B. Health benefits of fruits and vegetables. Adv Nutr. 2012; 3(4):506-16.

2. Deka SC., Seth D and Hulle NRS. Department of Food Engineering and Technology. Chapter 1: Food bioactives: functionality and applications in human health". Apple Academy Press; 2019.

3. Sajem AL, Gosai K. Traditional use of medicinal plants by the Jaintia tribes in North Cachar Hill District of Assam, Northeast India. J Ethnobiol Ethnomed. 2006;2:33.

4. Sharma UK, Pegu S. Ethnobotany of religious and supernatural beliefs of the Mising tribes of Assam with special reference to the "Dobur uie". J Ethnobiol Ethnomed. 2011;7:16.

5. Sethiya NK, Shekh MR and Singh PK. Wild banana [Ensete superbum (Roxb) cheesman]: ethnomedicinal, phytochemical and pharmacological overview. Journal of Ethnopharmacology; 2019 p 218-233.

6. Mathew NS. and Negi PS. Traditional uses, phytochemistry and pharmacology of wild banana (Musa Acuminate Colla): a review. Journal of Ethnopharmacology; 2017 p 124-140

7. Chanda S, Sarathy IP., De B and Singh K. Paederia foetida - a promising ethno medicinal tribal plant of north eastern India. Journal of Forestry Research; 2013 p 801-808.

8. Narzary Y, Brahma J, Brahma C, Das S. A study on indigenous fermented foods and beverages of Kokrajhar, Assam, India. Journal of Ethnic foods. 2016:3:284-91.

9. Borges $\mathrm{CV}$ et al. Bioactive amines changes during the ripening and thermal processes of bananas and plantains. Food Chemistry; 2019 p 298.

10. Pranita D, Devi LP, Gogoi M. Nutrient composition of some regional recipes of Assam. India Ethno-Med. 2009;3(2):111-7.

11. Amah $\mathrm{D}$, et al. Recent advances in banana (musa spp) biofortification to alleviate vitamin A deficiency. Crit Rev Food Sci Nutr. 2019;59(21):3498-510.

12. Khokhar S, Ashkanani F, Garduno Diaz SD, Husain W. Application of ethnic food composition data for understanding the diet and nutrition of South Asians in the UK. Food Chem. 2013;140(3):436-42.

13. Khujani AA, Birch J, Bekhit AEA. Production, application and health benefits of banana pulp and peel flour in the food industry. J Food Sci Technol. 2019;56(2):548-59.

14. Baruah AM, Borah S. An investigation on sources of potential minerals found in traditional vegetables of North east India. Int J Food Sci Nutr. 2009; 60(4):111-5

15. Liyanage R. et al. Banana blossom (Musa acuminate Colla) incorporated experimental diets modulate serum cholesterol and serum glucose level in Wistar rats fed with cholesterol; 2016: 9747412.

16. Singh B, Singh JP, Kaur A, Singh N. Bioactive compounds in banana and their associated health benefits - a review. Food Chem. 2016;206:1-11.

17. Dehingia $\mathrm{M}$, et al. Gut bacterial diversity of the tribes of India and comparison with the worldwide data. Sci Rep. 2015;5:18563. https://doi.org/ 10.1038/srep18563.

18. Betlu S. Indigineous knowledge of zootherapeutic use among the Biate tribe of Dima Hasao District, Assam, Northeast India. J Ethnobiol Ethnomed. 2013;9:56.

19. Teronpi V, Singh HT, Tamuli HT, Teron R. Ethnozoology of the Karbis of assam, India: use of ichthyofauna in traditional health care practices. Anc Sci Life. 2012;12(2):99-103.

20. Hemanta MR, Mane VK, Bhagwat A. Analysis of traditional food additive Kolakhar for its physico-chemical parameters and antimicrobial activity. J Food Process Technol. 2014;5:11.

21. Jaiswal P, et al. Prediction of textural attributes using colour values of banana (Musa sapentum) during ripening. J Food Sci Technol. 2014;51(6): 1179-84.

22. Pereira A, Maraschin M. Banana (Musa spp) from peel to pulp: ethnopharmacology, source of bioactive compounds and its relevance for human health. J Ethnopharmacol. 2015;160:149-63.

23. Padam BS, et al. Banana by products: an underutilised renewable food biomass with great potential. J Food Sci Technol. 2014;51(12):3527-45.

\section{Publisher's Note}

Springer Nature remains neutral with regard to jurisdictional claims in published maps and institutional affiliations.

\section{Ready to submit your research? Choose BMC and benefit from:}

- fast, convenient online submission

- thorough peer review by experienced researchers in your field

- rapid publication on acceptance

- support for research data, including large and complex data types

- gold Open Access which fosters wider collaboration and increased citations

- maximum visibility for your research: over $100 \mathrm{M}$ website views per year

At BMC, research is always in progress.

Learn more biomedcentral.com/submissions 